\title{
気候条件が動物の発育に及ぼす影響について
}

\section{Growth of Young Animals Influenced by Bad Condition of Climate}

\author{
横浜医科大学衞生学教室 (主任 萩原兼文教授) \\ 大川 - 義 佐 藤 具 太郎 \\ Kazuyoshi Ôkawa Tomotarô Satô \\ Department of Hygiene, Yokohama Medical College \\ (Director: Prof. K. Hagiwara)
}

\section{1. まえがき}

高温・高湿などの環境気候条件が生体機能に及ぼす影 響に関する研究報告は多数及うけられ, 蛋白代謝および $\mathrm{CO}_{2}$ 代謝の充進, 肝機能の減退, 甲状腺機能の元進, 血中水分量の変動などについて，結果的にはいずれもそ の有害なるととを結論している。しかし，湿度の変化掠 よび換気不良に基づく生体機能の変化に関する研究業績 はそしく，特に幼若動物の成長発育に及ぼす影響につい ての記戴はまつたくそしい。

浦島"は Azorbin S 排泄試験による肝機能検査によつ て，その減退度は温度・湿度の高さに比例するが，その 程度は一般に軽く，かつ温度よりも湿度によつてょり多 く影響されるといつている。

河原 ${ }^{2}$ は湿度と食䬣量との関係について, 高湿環境で は食䬣量の減少が起り, さらにマウス抢よび十姉妹の体 重い，高湿環境下に打いた場合には自然的環境に捛いた 場合に比してその増加が不良であり，一般に減少傾向完 示し, また産仔数・産卵数も少宗く, 出生仔の発育も志 た著しい障害を受けると述べている。

田村 ${ }^{31}$ は30〜38 Cの高温乾燥室掞よび80〜100\% R.H. の高湿環境下における炭酸ガス産生量を測定したが, 乾 湿の影響山きわめて少ないといつている。

阪巻4) は中等度の温・湿度のもこに括いても無風状態 は肉体的運動の不足乞相俟つて, 鵎䇥の性的成熟を抑制 し, 一定の気流が存在すればこの抑制を免れて正常の成 熟をきたすことを実験的に証明した。

佐々木 ${ }^{5}$ 嫁鬼を用い, $\mathrm{A}$ 換気普通・ B 換気不良・ C 開放室の3つの異なる条件のもとでそれぞれ飼育実験を 括とない, 換気不良群では体重増加がもつとも不良であ
り，家鬼肺炎菌による罹病率おょび死亡率も高く，かつ その症状は重篤で病理学的所見も委た著明な変化を認め た。

以上のどとき諸家の業績によつて，高湿環境下におけ る生活が日常の人体生理諸機能にも若干の影響を及ぼ し, 特に幼若者の成長発育にもなんらかの影響をきたす であろろことは想察に難くない。

空気を洗滌浄化し, 温度および湿度を適宜に調整して 居住室内に送入し，もつて住居内部の環境を快適ならし めるとこもに換気の目的をも併せて達せんとする空気調 整 (Air Conditioning) は，近年その装置の進歩に伴な つて急速に利用範囲が拡大されてきた。かくのごとく人 為的に醸成された至適環境の中に生活を営むととは上記 の諸家の業績に鑑及て当然人体生理諸機能の好調を持続 しろるととになろらと考えられる ${ }^{6-9)}$ 。殊に，一般的に 高湿であることを特徴とするわが国の気象状況下に揖い て, 特に夏季の高温・高湿状態が食思減退・活動力低下 を招くものであるととは既に広く知られた事実である。

空近年種々の社会的制約を受けた必然の結果として 各地に続队と建設されきたつた鉄筋コンクリートアパー 卜は, 狭小な土地を可及的広範囲に利用し, 心つ霜震・ 耐火・耐久性の大なる住宅を多数建造して住宅難緩和を 可及的速やかに達成せんとする国策的処置の産物である が, 施工時のコンクリート凝結水の元の後の蒸散, 完工 後の降雨なざに基づく再吸水, さらにとのコンクリート

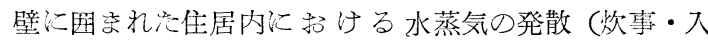
浴なご）などによつて住居環境が容易に高湿状態とな り10,11,13,14)，“冨がじめじ的している”之ふ“夜具がい つもしめつぽい”などと室内気候の高湿なるととを示唆 する居住者の訴え汸多数にのぼつている ${ }^{1211^{14}}$ 。 
佐藤 ${ }^{14}$ のコンクリートアパートに招ける 1 年有半にう たる諸種一連の実測研究によつて、コンクリートアパー トでの屋内気候が常に木造住宅のそれに比して高湿であ つたとと，盢などの建具類，押入に収納する日常使用の 夜具の含湿率が常時高値を示したてとなどが判明して， 総じてコンクリートアパートは木造住宅に比して高湿環 境であり, 自然換気もきわめて僅少であることが明らか となつた。

空気調整による至適環境の造成と,コンクリートアパ 一トに抢ける高湿居住環境との，2つの相反する事実の 相互関連について若干の考察を試みるべく, 高湿状況下 での幼若動物の発育について実験的研究を抢こなつた。

\section{2. コンクリートアパートで飼育したラッテ の発育について}

ウィスタ系ラッテ雄, 生後 2 カ月, 体重 $100 \mathrm{~g}$ のもの 5 匹学飼育箱に入れ, アパート内のほ添中央位置, 台所 ・玄関境界の板張り林上に执いて，オリエンタル固型飼 料おょび水は無制限に投与して体重増加の推移を観察し た。な拉対照として同じ時期に同様の方法で木造住宅内 で飼育し観察した。観察期間中の環境（気候）条件は， コンクリートアパートでは温度 $10 \pm 1.5{ }^{\circ} \mathrm{C}$, 湿度 $78 \pm 5$ $\%$ ，木造住宅では温度 $9.5 \pm 1.5{ }^{\circ} \mathrm{C}$, 湿度 $57 \pm 10 \%$ あ つた。したがつて飼育条件での相違は場所㧤よびその環 境湿度である。その結果, 体重の推移状況は第 1 図に示 すごとくであつて，両群について体重差（平均の）を一 元配置法によつて検討すると18日目に扢いて危険率 1\% で有意の差を認めた。すなわち，コンクリートアパート 内で飼育したラッテは木造住宅で飼育したラッテに比し てその体重増加が著しく劣ることが立証された。

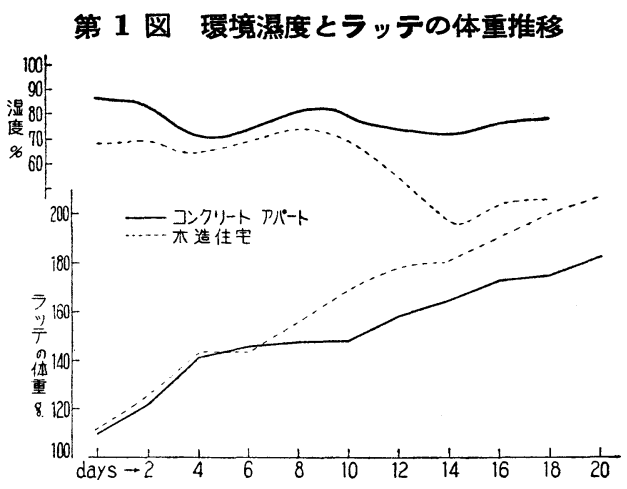

\section{3. 高濕環境に飼育したマウスの発育について}

容積約 $0.5 \mathrm{~m}^{3}$ の密閉可能な飼育箱に D D 系マウス 15
匹を収容し，オリエンタル固型飼料㧠び水を無制限に 投与して飼育し, その体重増加の推移を観察した。環境 条件としては

A. 温度 $23 \pm 1{ }^{\circ} \mathrm{C}$ 水道永中を通過せしめて水蒸気飽 和状態とした空気を毎分 $10 l$ の速度で飼育箱内に送入， この箱内では温度 $27 \pm 2{ }^{\circ} \mathrm{C}$, 湿度は $92 \pm 5 \%$

B. 実験室に打ける通常空気学毎分 $5 l$ の速度で 飼育 箱内に送入，乙のときの箱内では温度 $27 \pm 2{ }^{\circ} \mathrm{C}$, 湿度は $87 \pm 5 \%$

C. 実験室内に扔いて開放性飼育箱内で無処理のまま 飼育，乙の環境は温度 $26 \pm 2{ }^{\circ} \mathrm{C}$, 湿度は $73 \pm 7 \%$

以上 $\mathrm{A} \cdot \mathrm{B} \cdot \mathrm{C} 3$ 群忌れぞれ15匹ずつの平均体重の推 移むょび環境湿度の状況㳊第 2 図に示すごとくである。 客㧍各群の生存匹数扮よび平均体重は第 1 表に示す。

\section{第 2 図 環境缹度と体重増加}

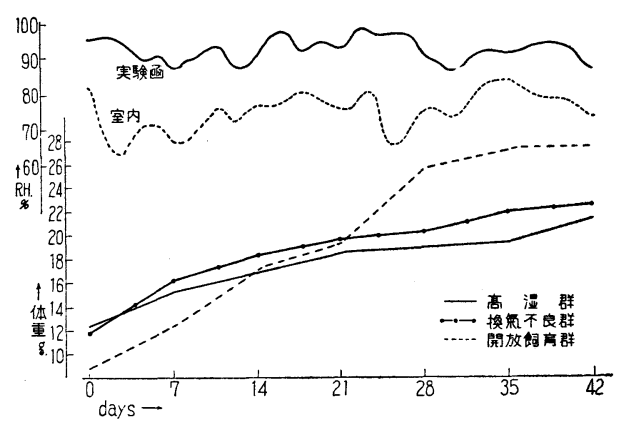

第 1 表 各群生存数と平均体重の推移

1) 生存数

\begin{tabular}{l|c|c|c|c|c|c|c}
\hline & 前 & 7 日 & 14 日 & 21 日 & 28 日 & 35 日 & 42 日 \\
\hline 高 湿 群 & 15 & 12 & 11 & 11 & 11 & 11 & 9 \\
換気不良群 & 15 & 14 & 14 & 14 & 14 & 12 & 11 \\
開放飼育群 & 15 & 14 & 14 & 14 & 14 & 14 & 14 \\
\hline
\end{tabular}

2) 平均体重

\begin{tabular}{l|r|c|c|c|c|c|c}
\hline & 前 & 7 日 & 14 日 & 21 日 & 28 日 & 35 日 & 42 日 \\
\hline 高 湿' 群 & 12.38 & 16.73 & 17.67 & 18.36 & 19.09 & 19.45 & 21.77 \\
換気不良群 & 11.85 & 18.28 & 18.33 & 19.57 & 20.28 & 22.00 & 22.67 \\
開放飼育群 & 8.78 & 12.42 & 17.71 & 19.27 & 25.71 & 27.14 & 27.78 \\
\hline
\end{tabular}

$\mathrm{A}$ 群はきわめて高湿な状況下に扔いて，しかも換気の やや不充分な状態に扮かれて抢り，B群は換気不良の状 態にある故にマウス自身の生活機能に基づく排出水分の ために比較的高湿状態をかもし出されたものと解すべき であろう。そしてC群はまつたく自然のま委放置され生 
活したものである。かくて，体重推移を 比較検討する と, $\mathrm{A}$ 群抢よび $\mathrm{B}$ 群と $\mathrm{C}$ 群との間には28日目において危 険率 $1 \%$ で有意の差を認めた。守なわち，A高湿環境群 乞 B 換気不良群と注開放的に飼育した場合 ( C 群) に比 して体重増加が著しく劣ることが判明した。

さらにこの 3 群について大川 ${ }^{15}$ の案出せる遊泳時間の 測定による総合的体力の判定を扔こなつたが, 水温 $23^{\circ} \mathrm{C}$ でマウス数匹ずつを遊泳せしめて溺死するに至るなでの 時間 (分) を計測した結果では，高湿群掞よび換気不良 群では最短 7 分, 最長 260 分で平均は 148 分, 乙元に対 乙開放飼育群では最短 25 分, 最長 270 分で平均は 156 分 となつた。したがつて体重增加では劣弱省認めたけれぞ も，心・肺機能招よび全筋力を動員する総合的体力には 著明な差を認めなかつた。もつとも, 第 1 表の生存数保 よつて明らかなごとく高湿群掞よび換気不良群にあって は体力の 比較的劣弱なものは 飼育観察期間中に 死亡し て, 体力判定実験の際には体重が対照開放群に劣るとい えぞも体力は比較的強いものが残つていたとも考えられ るが，てれを確認することはできなかつた。

\section{4. 考 察}

居住環境気候のいかんによつて生体の生理諸機能に影 響・変化を招来するてとは既に多くの業績によつて明ら かである。近年その利用が急激に膨張し広範囲となつて きた空気調整によつて, 特に夏季の高湿状態から逃避す るととは, 生理機能を健常ならしめて作業能率を向上せ しむるに役立つととは疑ない。志たその反面においては 社会的制約に基づいて続々と建設されきたつたコンクリ ーリアパートは, その構造体の性質から住居内環境が高 湿に陌りやすい。したがつて，とのコンクリートの箱の 中に常時生活を営む場合には，高湿なるが故化生理諸機 能に及汸す影響もまた少なからずと考えられ，レにがつ て上記のごとき実験を試みたのである。

その結果，コンクリートアパートでは木造住宅に比し て常時約20\%高湿であつて, そこ飼育したラッテの体
重増加が著しく劣ることが判明し, 実験的に高湿環境抏 よび換気不良環境学醄成して飼育したマウスは，開放的 に飼育した場合より体重增加が著しく劣ることが判明し た。参沶ラッテは低温季節に, マウスは高温季節飞実験 観察を抢しなつたのであるが, いずれの場合にも対照群 との環境条件の差は湿度が高いととの及であつて之の差 屾約 $20 \%$ にもんでいる。したがつて, 両実験の結果か 引, 高湿環境なるが 故に生理機能に若干の障害を及济 し, 体重增加, すなわち発育に劣弱化をきたしたものと 考えるべきであろう。

\section{5. 結 語}

高湿居住環境に怙いてラッテ捛よびマウスを飼育して その発育を観察した。ラッテは冬季化，マウスは夏季に 飼育し, それぞ㣗共通寸る環境条件は対照群の飼育環 境に比し約20\%高湿であるととの及であつた。いずれの 場合にも, 発育が阻害されて体重増加が対照群に比して 著しく劣弱であつた。

終りに臨み本実験に関し直接御指導をいただいた教室 の都筑講師に対し謝意を捧げます。

\section{文献}

1）浦島：海軍々医会雑誌，33：93，昭 19.

2) 河原：国民衞生，10:1047, 昭 8 .

3) 田村：大日本麦酒科学研究所生物化学業績集, 1 : 23 , 昭 17 .

4) 阪巻: 日本聯合衞生学会誌, $13: 61$, 昭 16 .

5）佐々木：日本聯合衞生学会誌， $3: 14$, 昭 6 .

6）䔦原：日本衞生学雑誌，8:193, 昭 29 .

7）吉田：国民衞生， $12: 1$, 昭 10 .

8）荻野: 衞生工業協会誌, $9: 317,371,438,608$.

9）鯉沼：衞生工業協会誌， $8: 1$.

10）西藤：建築技術， 20 号，昭 22 .

11）室賀：日本建築学会研究報告集, 28 号, 昭 29 .

12）谷：建筑技術, 20 号, 昭 22 .

13）佐藤：佳居衞生学, 績交堂, 昭 32 .

14）佐藤具太郎: 未刊資料.

15）大川一義: 未刊資料.

(受付 : 1958 年 10 月 1 日, 特別掲載) 